\title{
Food safety system application during production of ice cream
}

\section{Mohamed Farag Moahmmady, Asmaa Sayed Abdel Wahid, and Aliaa Mohamed Hashem}

- National Nutrition Institute

\section{ABSTRACT}

I

ce cream is one of the main dairy products and a nutritionally food. It is one of the favorite food items to a large segment of the hygienic quality of ice cream through the application of Food Safety System. Ninety samples were collected during the production of ice cream. Thirty samples were collected before the application of the system; thirty samples were collected after the application of the system and thirty samples were collected from swabs. The samples were examined for the presence of, coliforms, fecal coliforms, Bacillus cereus, Staphylococcus aureus, mold, and yeast count. The obtained results indicated that the microbial count of samples before the application of the Food Safety System was higher than those after the application of the system. They ranged between $1.2 \times 106$ to $1.8 \times 103$, $8.0 \times 101$ to negative, $2 \times 102$ to negative, $7.0 \times 102$ to $1.9 \times 102$ and 2.4 $\times 105$ to $2.3 \times 103 / \mathrm{gm}$ in the packaging stage at aerobic total count, coliforms, Bacillus cereus, Staphylococcus aureus, mold and yeast count respectively, while fecal coliforms were not detected in both before and after system application.

Keywords: Food safety system-ice cream production 
INTRODUCTION:

The application of Food Safety System can aid in inspection by regulatory authorities through focusing on the matters of high health risk and promote domestic and international trade by increasing confidence. In addition to enhanced food safety, the benefits of applying HACCP include better use of resources and more timely response to production problems Chen et al (2013).

Food safety has become a main thing in the world making public health agencies and governments of several countries look for more efficient ways to monitor production chains. Food Safety System is a means to ensure the safe production of food products. It is an assurance system based on the prevention of food safety problems and is accepted by the international authorities as the most effective means of controlling food-borne diseases. The implementation of food safety system will produce the safe food and suggest the control measures because it will improve the quality of ice cream United Nations Codex Alimenterius, (2003).

HACCP, as a food safety assurance program, requires continuous monitoring of established critical limits at ccp and the verification of evaluation compliance with the approved HACCP plan (WHO, 1995).

Ice cream is one of the main dairy products. It is one of the favorite food items to a large segment of the population. It is a nutritionally and an enriched frozen dairy product consumed by all age groups particularly by children and mostly during summer. Ice cream is sold in a package form (cups, cones, and cartons). 


\section{AIMS OF THE WORK}

1. Assessment of hygienic quality of ice cream through the application of Food Safety System.

2. Finding the critical control point by observing each step of the production operation.

\section{Materials and methods:}

This study was carried out at a company in Cairo for 10 months. Visit intervals were once a week.

The total number of samples analyzed was: thirty samples that were collected before the application of Food Safety System; five samples were taken from each step, thirty samples were collected after the application of Food Safety System then 30 swab samples that were taken from tables, walls and food handlers.
All of these samples were tested for the identification microbial hazards included: aerobic total count, coliforms, fecal coliforms, Bacillus cereus, Staphylococcus aureus and mold and yeast count.

Samples were collected in sterile bags and kept inside an ice box until they reached the laboratory.

The microbial procedures were recommended in the International Commission on Microbiological Specifications for Foods (ICMSF 1978, 1995).

Ice cream consisted of packaged frozen mixture of raw milk, fat, skimmed milk, sugar and vanilla which was exposed to $75^{\circ} \mathrm{c}$ then suddenly cooled to $4^{\circ} \mathrm{c}$ before being frozen at $-2^{\circ} \mathrm{c}$. This product is consumed by all population. 
Sugar, raw milk, skimmed milk powder, fat, $\leq 10^{\circ} \mathrm{c}$

Mixing of ingredients

CCP 1

Pasteurization

CCP 2
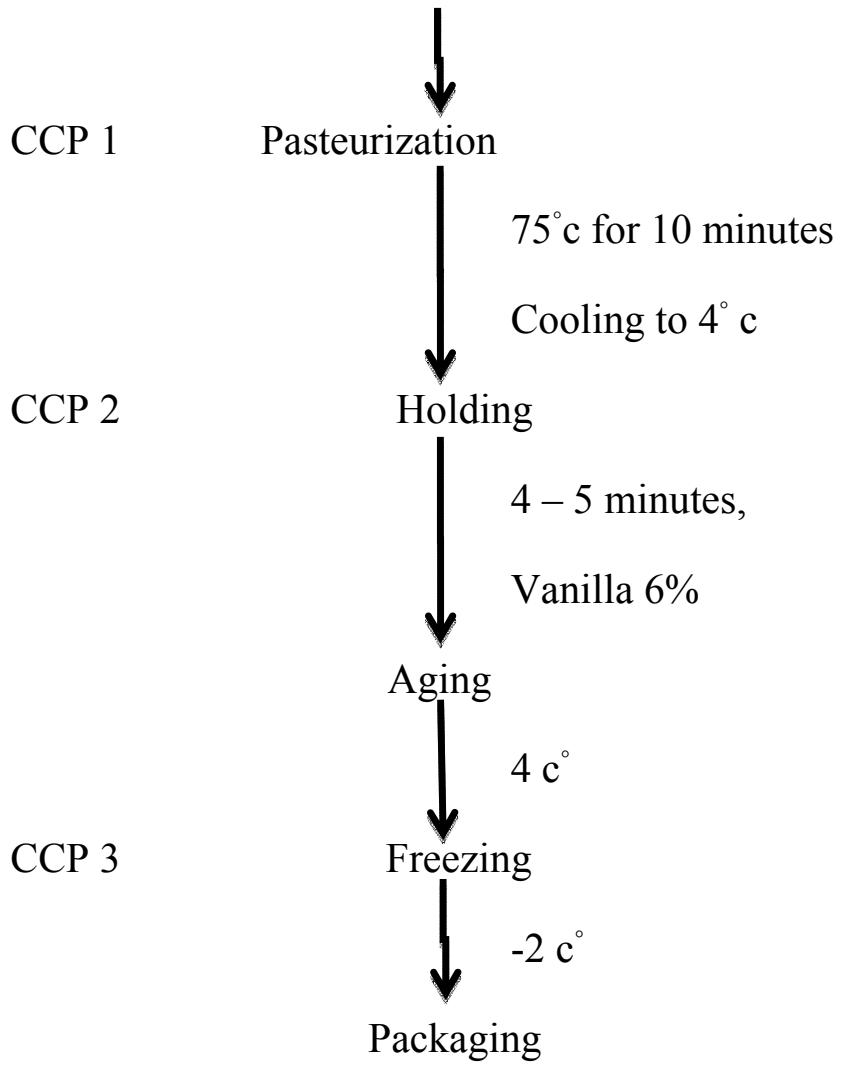

Flow diagram of ice cream production process 
RESULTS and DISCUSSION:

Table (1) illustrates the microbial counts of ice cream produced before food safety system application. It can be seen from the table that the aerobic count, mold and yeast were higher in both mixing ingredients and packaging steps than in the other steps. The table also shows that no growth of fecal coliforms was found in all the steps. Staphylococcus aureus was found in receiving of raw milk and transferred from hands to udder and milk during milking and from microbial contained in improperly cleaned equipment, microbial growth during storage and delivery Giffe et al (1996) and Sharof et al (1989).

Table (2) shows the hazard analysis chart of ice cream production. It can be seen from the table that the hazards in all the production steps of ice cream were microbial survival and growth, cross contamination and environmental contamination. The preventive measures included the use of safe ingredients, safe utensils and tanks, clean environment, control of time and temperature, the application of sanitary measures and personal hygiene of food handlers. Yu-Ting Hung et al, 2015 noticed that the monitoring of $\mathrm{CCP}$ is essential to ensure that the specific criteria are being met. Monitoring procedures were implemented by the HACCP team to ensure that all CCPs were under control.

Table (3) shows the HACCP control chart of ice cream production. It can be seen from the table that the critical limit of the holding step was cool and hold at $4 \mathrm{c}^{\circ}$ for 5 minutes. The critical limit of step 2 was to heat at $75 \mathrm{c}^{\circ}$ for 10 minutes and the critical limit of step 5 was freezing at $-2 \quad c^{\circ}$. The procedure of monitoring in 
all the steps of ice cream production was of time and temperature measurement. The corrective actions of step 2 was re-heating at $75 \mathrm{c}^{\circ}$ and then re-cooling suddenly at $4 \mathrm{c}^{\circ}$ for 5 minutes (pasteurization) Kassem et al, (2010).

Table (4) shows the microbial counts of a random sample during ice cream production taken after the application of HACCP. It can be seen from the table that after HACCP application both the aerobic total count and mold and yeast count were higher during mixing of ingredients than in the other steps. The aerobic total count during mixing of ingredients was $4.3 \times 10^{4}$, this decreased to $1.8 \times 10^{3}$ during packaging. On the other hand, mold and yeast decreased from $2.8 \mathrm{x}$ $10^{5}$ during the mixing of ingredients step to $2.3 \mathrm{x}$ $10^{3} \mathrm{cfu} / \mathrm{g}$ during packaging. Also, the table shows that both Bacillus cereus $(7.0 \mathrm{x}$ $\left.10^{1}\right)$ and coliforms (4.5 x $\left.10^{1}\right)$ were identified only during the mixing of ingredients step. Staphylococcus aureus was detected in all the production steps. Mean counts ranged between $1.0 \times 10^{2}$ and $1.6 \mathrm{x}$ $10^{2}$ colony/g. Kassem et al (2010) reported that microorganisms were found to survive in the degree $\left(\leq 10^{\circ} \mathrm{C}\right)$ and also could be attributed to poor hygienic conditions and lack of sanitation.

Table (5) shows a comparison between the microbial counts before and after HACCP application during ice cream production. It can be seen from the table that the microbial counts before HACCP application are higher in all the steps than after HACCP application, whereas, the growth of fecal coliforms was negative in all the steps of ice cream production both before and after HACCP application. Bacillus cereus 
was not detected after HACCP application in all the production steps except during the mixing of ingredients step. On the other hand, Staphylococcus aureus decreased after HACCP application in all the production steps. El Tawila (2001) also reported that the decrease in the microbial count after HACCP system application indicated its successful application at food establishments.

Table (6) shows the microbial count of swab samples taken from tables, walls and food handlers. It can be seen that the swabs from the tables had aerobic bacteria, mold and yeast and coliforms of $5.0 \times 10^{2}, 1.7 \times$ $10^{4}$ and 2.0 organisms, 30 $\mathrm{cm}^{2}$, while no growth of other microorganisms was found. The aerobic bacteria and mold and yeast were 3.1 x $10^{3}$ and $3.0 \times 10^{3} \mathrm{cfu} / \mathrm{cm}^{2}$ respectively in walls, while no growth of other microorganisms was found on the walls. Also, the aerobic bacteria, coliforms, Staphylococcus aureus and mold and yeast were $3.0 \mathrm{x}$ $10^{2}, 3.0,4.0 \times 10^{2}$ and $1.0 \mathrm{x}$ $10^{2}$ respectively from food handlers, while no growth of other microorganisms was found. Food handlers, walls, tables and utensils which were used during the production of ice cream were unclean and unsafe. The satisfactory cleaning of equipment, utensils, walls and tables is very important (Bryan 1981) and ( Bryan 1991). Poorly cleaned utensils, equipment and tables' surfaces are known to harbor and promote the spread of microorganisms (Aureliet al 1996).

\section{REFERENCES}

Aureli P; Ferrini AM and
Mannoni V:
Presumptive
identification of
Sulphanomide and
antibiotic residues in 
milk by microbial inhibitor tests. Food Control, 1996; \& (3): 165-168.

\section{Bryan FL:}

Hazard Analysis Critical Control Point concept dairy food and environmental sanitation. Food Safety consultation and training, 1990; 10 (7): 416-418.

Bryan FL:

Hazard analysis of food service operations. Food Technology, 1991; 35 (2): 7887.

Chen YC; Liao CD; Lin HY; Ghiueh LG; Shih DYG:

Survey of aflatoxin contamination in peanut products in Taiwan from 1997 to 2011. J. Food Drug Anal 2013; 21: 24752.
El Tawila M:

Application of HACCP in ice cream production plants, 2001, 17 - 17 June 2001, Alexandria.

Giffel MC; Benmer RR; Saghuis BA; Rombours FM and TeGiffel MC:

Occurrence and characterization of (Psychotropic)

Bacillus cereus on farms in the Netherlands.

Symposium on

Bacteriological quality of raw milk, Wolgpassing, Australia.

International Dairy Federation, Brussels, Belgium, 1996; 4045.

ICMSF (International

Commission on Microbiological Specifications for Foods (1978): 
Microorganisms in foods. Their significance and methods of enumeration (2nd Ed, Toronto University of Toronto press.

\section{ICMSF (International \\ Commission \\ on \\ Microbiological}

Specifications for Foods (1992):

Microorganisms in Food, $1^{\text {st }}-$ Their significance and method of enumeration $-2^{\text {nd }}-$ Undu University of Toronto Press, Toronto, 1992.

Kassem MM; El-sayed AH; Gamil H; farid MF and Mohamedy MF(2010):

Food safety application on fruit juices consumed by internal tube feeding patients in Kasr ElAini new teaching hospital kitchen. Bulletin of national nutrition institute of the Arab Republic of Egypt.

Sharof OM; Hewedy MM
and Tawfek NF (1989):
Studies of the
bacterial flora of raw
milk in Fayoum
markets.
Journal of Fypt:
Sciences; $17 \quad(1-2)$ :
153-160.

United Nations Codex Alimenterius Commission's (2003):

$\mathrm{HACCP}$ and guidelines for its application (Revision of 2003)

WHO, World Health Organization (1995):

Training considerations for the application of the Hazard Analysis Critical Control Point system to food processing and manufacturing, 1995. 
Food safety system application during production of ice cream

Moahmmady MF; Abdel Wahid AS and Hashem AM

Yu-Ting H; Chi-Te; I-Chin

H; Roch-Chui $Y$ and

Kuan-Chen C, (2015):

The implementation

of hazard analysis

and critical control

point management

system in a peanut

butter ice cream

plant. 
Table (1): The microbial counts of ice cream produced before Food safety system application

\begin{tabular}{|c|c|c|c|c|c|c|}
\hline $\begin{array}{c}\text { Microbial } \\
\text { test }\end{array}$ & $\begin{array}{l}\text { Mixing of } \\
\text { ingredients }\end{array}$ & Pasteurization & Holding & Aging & Freezing & packaging \\
\hline $\begin{array}{l}\text { Aerobic total } \\
\text { count }\end{array}$ & $2.3 \times 10^{6}$ & $1.2 \times 10^{3}$ & $1.6 \times 10^{3}$ & $2.0 \times 10^{3}$ & $3.7 \times 10^{3}$ & $1.2 \times 10^{6}$ \\
\hline Coliforms & $7.0 \times 10^{1}$ & $5.0 \times 10^{1}$ & $7.0 \times 10^{1}$ & $7.8 \times 10^{1}$ & $7.8 \times 10^{1}$ & $8.0 \times 10^{1}$ \\
\hline $\begin{array}{c}\text { Fecal } \\
\text { coliforms }\end{array}$ & $-\mathrm{ve}$ & $-\mathrm{ve}$ & - ve & - ve & - ve & - ve \\
\hline Bacilluscereus & $78.0 \times 10^{1}$ & $3.0 \times 10^{1}$ & $3.0 \times 10^{1}$ & $1.0 \times 10^{2}$ & $1.0 \times 10^{2}$ & $1.2 \times 10^{2}$ \\
\hline Staph.aureus & $1.6 \times 10^{2}$ & $1.3 \times 10^{2}$ & $1.3 \times 10^{2}$ & $1.5 \times 10^{2}$ & $1.5 \times 10^{2}$ & $7.0 \times 10^{2}$ \\
\hline Mold \& yeast & $3.4 \times 10^{5}$ & $3.7 \times 10^{3}$ & $4.0 \times 10^{3}$ & $4.0 \times 10^{3}$ & $4.2 \times 10^{3}$ & $2.4 \times 10^{5}$ \\
\hline
\end{tabular}

Mean number of samples $=6$ from each step 


\section{Table (2): Hazard analysis chart of ice cream production}

\begin{tabular}{|c|c|c|}
\hline Process Step & Hazard & Preventive Measures \\
\hline $\begin{array}{ll}\text { 1- } & \text { Mixing of } \\
& \text { ingredients }\end{array}$ & $\begin{array}{l}\text { High load of } \\
\text { microorganisms } \\
\text { - } \begin{array}{l}\text { Cross contamination } \\
\text { from utensils and food } \\
\text { handlers }\end{array} \\
\text { - Environmental } \\
\text { contamination }\end{array}$ & $\begin{array}{l}\text { - Use of safe ingredients } \\
\text { - Use clean and safe utensils } \\
\text { (GMP) } \\
\text { - } \begin{array}{l}\text { Personal hygiene during } \\
\text { mixing (GMP) }\end{array} \\
\text { - Clean environment (GMP) }\end{array}$ \\
\hline 2- Pasteurization & - Microbial survival & - Time and temperature control \\
\hline 3- Holding & $\begin{array}{l}\text { - Spores germination } \\
\text { - Cross contamination } \\
\text { during holding in the } \\
\text { storage tank }\end{array}$ & $\begin{array}{l}\text { - } \quad \text { Time and temperature control } \\
\text { - } \quad \text { Clean tank (GMP) }\end{array}$ \\
\hline 4- Aging & $\begin{array}{l}\text { - } \begin{array}{l}\text { Multiplication of } \\
\text { microorganisms }\end{array} \\
\text { - } \begin{array}{l}\text { Microbial cross } \\
\text { contamination from } \\
\text { utensils and the tank }\end{array}\end{array}$ & $\begin{array}{l}\text { - Time and temperature control } \\
\text { - Use clean tank and utensils } \\
\text { (GMP) }\end{array}$ \\
\hline 5- Freezing & $\begin{array}{l}\text { - Growth multiplication of } \\
\text { microorganisms }\end{array}$ & - Time and temperature control \\
\hline 6- Packaging & $\begin{array}{l}\text { Multiplication of } \\
\text { microorganisms } \\
\text { - Cross contamination } \\
\text { from wrapping } \\
\text { materials, food handlers } \\
\text { and the environment }\end{array}$ & $\begin{array}{l}\text { - } \quad \text { Time and temperature control } \\
\text { - } \quad \text { Clean wrapping materials } \\
\text { - } \quad \begin{array}{l}\text { Cleaning and disinfecting of } \\
\text { the packaging line }\end{array} \\
\text { - } \begin{array}{l}\text { Application of sanitary } \\
\text { measures and personal } \\
\text { hygiene of food handlers }\end{array}\end{array}$ \\
\hline
\end{tabular}



Moahmmady MF; Abdel Wahid AS and Hashem AM

Table (3): HACCP control of ice cream production

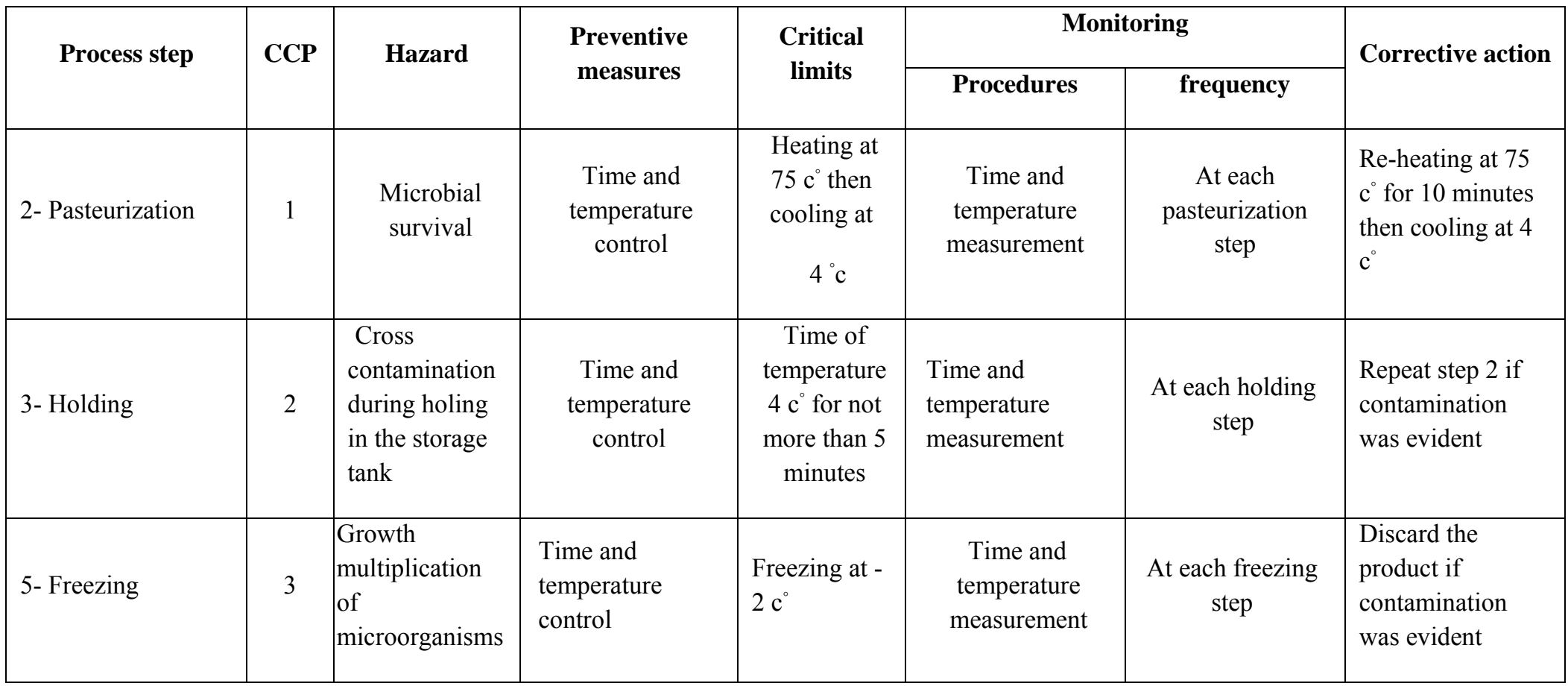


Moahmmady MF; Abdel Wahid AS and Hashem AM

Table (4): The microbial counts of a random sample during ice cream production taken after the application of HACCP

\begin{tabular}{|l|c|c|c|c|c|c|}
\hline \multicolumn{1}{|c|}{ Microbial test } & $\begin{array}{c}\text { Mixing of } \\
\text { ingredients }\end{array}$ & Pasteurization & Holding & Aging & Freezing & Packaging \\
\hline Aerobic total count & $4.3 \times 10^{4}$ & $2.1 \times 10^{1}$ & $2.3 \times 10^{2}$ & $3.2 \times 10^{2}$ & $1.2 \times 10^{3}$ & $1.8 \times 10^{3}$ \\
\hline Coliforms & $4.5 \times 10^{1}$ & $-\mathrm{ve}$ & $-\mathrm{ve}$ & $-\mathrm{ve}$ & $-\mathrm{ve}$ & $-\mathrm{ve}$ \\
\hline Fecal coliform & $-\mathrm{ve}$ & $-\mathrm{ve}$ & $-\mathrm{ve}$ & $-\mathrm{ve}$ & $-\mathrm{ve}$ & $-\mathrm{ve}$ \\
\hline Bacilluscereus & $7.0 \times 10^{1}$ & $-\mathrm{ve}$ & $-\mathrm{ve}$ & $-\mathrm{ve}$ & $-\mathrm{ve}$ & $-\mathrm{ve}$ \\
\hline Staphylococcusaureus & $1.6 \times 10^{2}$ & $1.0 \times 10^{2}$ & $1.0 \times 10^{2}$ & $1.0 \times 10^{2}$ & $1.0 \times 10^{2}$ & $1.0 \times 10^{2}$ \\
\hline Mold \& yeast & $2.8 \times 10^{5}$ & $4.1 \times 10^{2}$ & $2.1 \times 10^{3}$ & $2.1 \times 10^{3}$ & $2.1 \times 10^{3}$ & $2.1 \times 10^{3}$ \\
\hline
\end{tabular}


Moahmmady MF; Abdel Wahid AS and Hashem AM

Table (5): A comparison between the microbial counts before and after HACCP Application during ice cream production

\begin{tabular}{|l|c|c|c|c|c|c|}
\hline \multirow{2}{*}{ Microbial test } & \multicolumn{2}{|c|}{ Mixing of ingredients } & \multicolumn{2}{c|}{ Pasteurization } & \multicolumn{2}{c|}{ Holding } \\
\cline { 2 - 6 } & $\begin{array}{c}\text { Before } \\
\text { HACCP }\end{array}$ & $\begin{array}{c}\text { After } \\
\text { HACCP }\end{array}$ & $\begin{array}{c}\text { Before } \\
\text { HACCP }\end{array}$ & $\begin{array}{c}\text { After } \\
\text { HACCP }\end{array}$ & $\begin{array}{c}\text { Before } \\
\text { HACCP }\end{array}$ & $\begin{array}{c}\text { After } \\
\text { HACCP }\end{array}$ \\
\hline $\begin{array}{l}\text { Aerobic total } \\
\text { count }\end{array}$ & $2.3 \times 10^{6}$ & $4.3 \times 10^{4}$ & $1.2 \times 10^{3}$ & $2.1 \times 10^{1}$ & $1.6 \times 10^{3}$ & $2.3 \times 10^{2}$ \\
\hline Coliforms & $7.0 \times 10^{1}$ & $4.5 \times 10^{1}$ & $5.0 \times 10^{1}$ & - ve & $7.0 \times 10^{1}$ & - ve \\
\hline Fecal coliforms & $-\mathrm{ve}$ & $-\mathrm{ve}$ & $-\mathrm{ve}$ & $-\mathrm{ve}$ & $-\mathrm{ve}$ & $-\mathrm{ve}$ \\
\hline Bacilluscereus & $8.0 \times 10^{1}$ & $7.0 \times 10^{1}$ & $3.0 \times 10^{1}$ & $-\mathrm{ve}$ & $3.0 \times 10^{1}$ & $-\mathrm{ve}$ \\
\hline $\begin{array}{l}\text { Staphylococcus } \\
\text { aureus }\end{array}$ & $1.6 \times 10^{2}$ & $1.6 \times 10^{2}$ & $1.3 \times 10^{2}$ & $1.0 \times 10^{2}$ & $1.3 \times 10^{2}$ & $1.0 \times 10^{2}$ \\
\hline Mold \& yeast & $3.4 \times 10^{5}$ & $2.8 \times 10^{5}$ & $3.7 \times 10^{3}$ & $4.1 \times 10^{2}$ & $4.0 \times 10^{3}$ & $2.1 \times 10^{3}$ \\
\hline
\end{tabular}


Moahmmady MF; Abdel Wahid AS and Hashem AM

Con. table (5)

\begin{tabular}{|l|c|c|c|c|c|c|}
\hline \multirow{2}{*}{ Microbial test } & \multicolumn{2}{|c|}{ Aging } & \multicolumn{2}{c|}{ Freezing } & \multicolumn{2}{c|}{ packaging } \\
\cline { 2 - 6 } & $\begin{array}{c}\text { Before } \\
\text { HACCP }\end{array}$ & $\begin{array}{c}\text { After } \\
\text { HACCP }\end{array}$ & $\begin{array}{c}\text { Before } \\
\text { HACCP }\end{array}$ & $\begin{array}{c}\text { After } \\
\text { HACCP }\end{array}$ & $\begin{array}{c}\text { Before } \\
\text { HACCP }\end{array}$ & $\begin{array}{c}\text { After } \\
\text { HACCP }\end{array}$ \\
\hline $\begin{array}{l}\text { Aerobic total } \\
\text { count }\end{array}$ & $2.0 \times 10^{3}$ & $3.2 \times 10^{2}$ & $3.7 \times 10^{3}$ & $1.2 \times 10^{3}$ & $1.2 \times 10^{6}$ & $1.8 \times 10^{3}$ \\
\hline Coliforms & $7.8 \times 10^{1}$ & $-\mathrm{ve}$ & $7.8 \times 10^{1}$ & $-\mathrm{ve}$ & $8.0 \times 10^{1}$ & $-\mathrm{ve}$ \\
\hline Fecal coliforms & $-\mathrm{ve}$ & $-\mathrm{ve}$ & $-\mathrm{ve}$ & $-\mathrm{ve}$ & $-\mathrm{ve}$ & $-\mathrm{ve}$ \\
\hline Bacilluscereus & $1.0 \times 10^{2}$ & $-\mathrm{ve}$ & $1.0 \times 10^{2}$ & $-\mathrm{ve}$ & $1.0 \times 10^{2}$ & $-\mathrm{ve}$ \\
\hline $\begin{array}{l}\text { Staphylococcus } \\
\text { aureus }\end{array}$ & $1.5 \times 10^{2}$ & $1.0 \times 10^{2}$ & $1.5 \times 10^{2}$ & $1.4 \times 10^{2}$ & $7.0 \times 10^{2}$ & $1.5 \times 10^{2}$ \\
\hline Mold \& yeast & $4.0 \times 10^{3}$ & $2.3 \times 10^{3}$ & $4.2 \times 10^{3}$ & $2.3 \times 10^{3}$ & $2.4 \times 10^{5}$ & $2.3 \times 10^{3}$ \\
\hline
\end{tabular}


Table (6): The microbial count of the swab samples taken from table, wall, and food handlers.

\begin{tabular}{|l|c|c|c|}
\hline \multicolumn{1}{|c|}{ Microbial test } & Tables & Walls & Food handlers \\
\hline Aerobic total count & $5.0 \times 10^{2}$ & $3.1 \times 10^{3}$ & $3.0 \times 10^{2}$ \\
\hline Coliforms & 2.0 & - ve & 3.0 \\
\hline Fecal coliforms & - ve & - ve & - ve \\
\hline Bacilluscereus & - ve & - ve & - ve \\
\hline Staphylococcusaureus & - ve & - ve & $4.0 \times 10^{2}$ \\
\hline Mold \& yeast & $1.7 \times 10^{4}$ & $3.0 \times 10^{3}$ & $1.0 \times 10^{2}$ \\
\hline
\end{tabular}

Mean number of samples $=10$ swabs 



\section{تطبيق نظام سلامهة الغذاء أنهاء إنتاج الآيس كربم محمد فرج محمدي، أسماء السيد عبد الواحد، علياء محمد هاشم

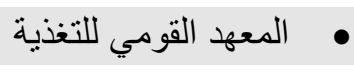

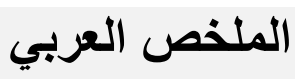

الآيس كريم من المنتجات ذات القيمة الغذائية العالية والدفضلة خاصة لدى

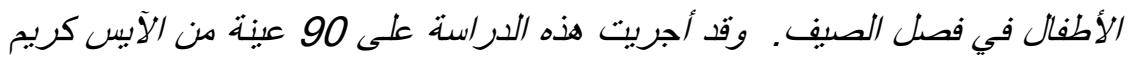

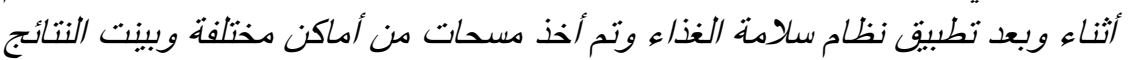

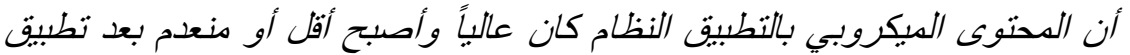

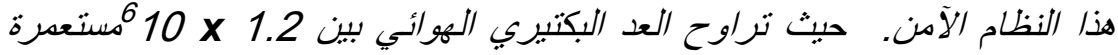
ميكروبية إلى 1.8 x 30 مستعدرة ميكروبية لكل جرام في مرحلة التعبئة.

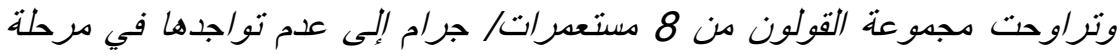

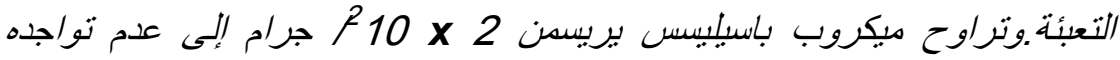

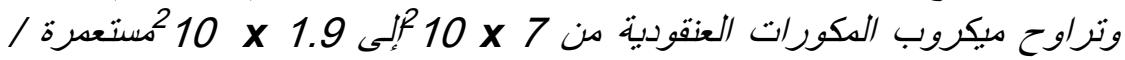

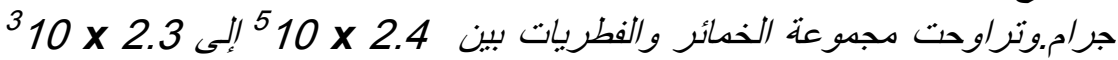

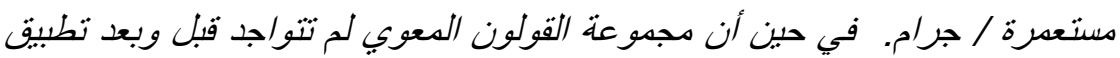

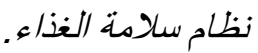
الكلمات المفتاحية: نظام سلامة الغذاءـ إنتاج الأبس كريم 